\title{
POSTCOLONIALISM, IDENTITY, AND THE FRENCH LANGUAGE IN ST. LUCIA
}

Due to its colonial history, St. Lucia is an amalgamation of African, French, and British cultural elements. The French were the first European colonial power to successfully establish permanent settlement on the island, instituting a plantation-based economy. Most St. Lucians today are descendants of enslaved Africans brought to the island by the French from neighboring Martinique, beginning in the mid-seventeenth century (Breen 1844). Although the French lost definitive colonial control over the island to the British in 1814, the legacy of early French colonialism is evident everywhere (Lowenthal 1972). The vast majority of place names are of French origin, Roman Catholicism remains the predominant religion and, most notably, more than 80 percent of St. Lucians speak Kwéyòl - a French-lexicon creole vernacular similar to those spoken in the French départements d'outre-mer of Martinique and Guadeloupe. Although Kwéyòl is still widely spoken in St. Lucia, English is the language of education, business, prestige, upward mobility, and international relations, and most St. Lucians also speak English. The British colonial legacy also lives on via St. Lucia's parliamentary form of government and educational system. Moreover, St. Lucia gained political independence from the United Kingdom in 1979 and, since then, the influence of U.S. culture has been on the rise as U.S.-dominated media have spread throughout the island and as greater numbers of St. Lucians have migrated to and from the North American mainland.

In the postcolonial era, Kwéyòl has become the most visible symbol of St. Lucian national identity. This is due in large part to the activities of the pro-Kwéyòl cultural nationalist movement which grew out of organized efforts in the early 1970 s to preserve and promote St. Lucia's Afro-French, creole culture (Carrington 1984, Dalphinis 1985, St. Hilaire 2000). As a result of the cultural nationalist movement, many contemporary St. Lucians value Kwéyòl as the homegrown, unique cultural property of their island. At the same time, however, English has become more firmly entrenched in St. Lucia. The continued expansion of the public school system has led to greater

New West Indian Guide / Nieuwe West-Indische Gids vol. 81 no. 1 \& 2 (2007):55-77 
facility in English among St. Lucians across the social spectrum. In postcolonial debates related to St. Lucian national identity within cultural nationalist circles, the focus has been on elevating the social status of Kwéyòl, but never to the detriment of English - highly regarded by St. Lucians of all stripes as a passport to upward and outward mobility.

The postcolonial era in St. Lucia is marked in part by a substitution of sociocultural forms dominant during the colonial period with more localized national variants. On the island, this phenomenon is witnessed by increased support by the public for Kwéyòl as an important symbol of St. Lucian cultural identity and by the national administration as an effective medium of communication with its citizenry - during the colonial period Kwéyòl was denigrated by the elite class and public officials as a language of ignorance and backwardness, and English was the sole language of officialdom. The postcolonial era is also marked by a diminution in anticolonial discourse on the island. As such, pragmatic concerns related to economic development and socioeconomic opportunities for St. Lucian citizens hold sway. Accordingly, the St. Lucian political establishment encourages the continued expansion of full literacy in Standard English through the island's schools, and parents make great sacrifices to ensure their children master the language. Relative to Kwéyòl and English, the current status of French on the island is somewhat ambiguous. French was a spoken language only during the island's early colonial history under slavery. Shortly after emancipation in 1834 French ceased to exist, with English coming to fill former high-status functions of French in island society. In the early 1980s, however, St. Lucian government officials, with financial and logistical support from the French national government, launched a program of expansion of French language instruction in all of the island's high schools. By the mid-1990s, the program was extended to include the last three grades of primary school across the island (Cassan 1996, Dumont 2004). Moreover, in 1984 France established a permanent Mission de coopération et d'action culturelle (MCAC) in St. Lucia - including an Alliance Française located in a prominent position on the bay in downtown Castries - to train St. Lucian teachers of French and to teach French to all interested St. Lucians.

The role of Kwéyòl in the formation of postcolonial St. Lucian national and cultural identity is relatively well documented. ${ }^{1}$ The predominant role English has played in the colonial and postcolonial economic, political, and cultural life of St. Lucia and St. Lucian attitudes toward the language are

1. Carrington 1984, Dalphinis 1985, Samuel 1992, Frank 1993, Nwenmely 1999, Garrett 2000, St. Hilaire 2000, 2003, and also Lawrence Carrington, 1987, Creole Discourse and Social Development, a report prepared for the Economic Commission for Latin America and the Caribbean for submission to the International Development Centre. 
also documented in the literature. ${ }^{2}$ However, the status of French in postcolonial St. Lucian society and the role the language plays in St. Lucian national and cultural identity has received relatively little research attention. St. Lucia became a member of the Francophonie in 1981 - participating in its programs of member cooperation and maintaining an active presence in venues of cultural and political representation. In addition, ties between both France and French-speaking Martinique, on the one hand, and St. Lucia, on the other, have solidified since St. Lucian national independence, and school-aged children across St. Lucia now have access to French-language instruction beginning in the primary grades. However, little is known about how St. Lucians perceive French - the language of an early colonial power and former defenders of slavery on the island. This article seeks to fill the research void, examining attitudes toward and cultural identification with the French language among St. Lucians through a postcolonial conceptual framework.

\section{Methodology}

A review of literature on postcolonialism, identity, and language, particularly in the Caribbean context, informs, and data from interviews with 100 St. Lucian respondents empirically ground, the research. The interview survey instrument consists of closed- and open-ended questions probing into St. Lucian attitudes toward and knowledge, use, and perceptions of the languages used on the island and into issues related to St. Lucian cultural and national identity. Of the 100 respondents, 60 are from metropolitan Castries and 40 are from rural Monchy. Castries, St. Lucia's capital and largest city, has historically served as the island's motor for socioeconomic, sociocultural, and sociolinguistic change. Sociolinguistic attitudes, patterns of language knowledge, and use and feelings of cultural and national identity held by Castries residents, therefore, are key to understanding the dynamics of St. Lucian identity vis-à-vis the French language islandwide. Monchy, a village located in the mountainous interior of north central St. Lucia, is in the historically most Kwéyòl-dominant district of the island. Residents of the village provide representation of rural St. Lucian perceptions of identity and attitudes toward French. The relatively small number of survey respondents limits the ability to make statistical inferences. In qualitative research, however, data collected from interviews are valuable to gaining a better understanding of the social dynamics under study (Knapik 2006, Myers 2006, Bennett \& Colin 2007).

The 100 Castries and Monchy respondents were randomly selected from each location, using census housing unit maps obtained from the St. Lucian

2. Carrington 1967, Valdman 1976, Chaudenson 1979, Vaughan 1979, Alexander 1981, Edward 1989, Isaac 1989, St. Hilaire 2000, 2003, Garrett 2003, 2006. 
Statistics Department. A single housing unit map was used for Monchy. Several housing unit maps, selected to include the central city and secondary and tertiary tiers, were used for Castries. The housing unit maps were demarcated for use by census takers. The informants were selected from every fourth house along the path delineated for census takers, alternating from right to left. The first person over the age of 13 to answer the door was asked to participate. If the invitation for participation was refused, the next fourth house on the alternate side of the route was selected. Of the selected 100 informants, 63 were female and 37 were male. In terms of age, 23 of the respondents were under 20 years old, 17 were 20-to-29 years old, 23 were 30-to-39 years old, 11 were 40to- 49 years old, 14 were 50-to-65 years old, and 12 were over 65 years old.

An English-language version of the interview questionnaire was administered to all but four older Monchy residents who did not speak the language - the Kwéyòl-language version of the questionnaire was crafted with the help of native Kwéyòl speakers. Survey questions designed explicitly to capture: 1) informant self-declared knowledge and use of French, 2) informant support for and attitudes toward this language, and 3) informant perceptions of St. Lucian cultural affinity with Martinique versus Barbados, and France versus the United Kingdom provide the primary data underpinning this article. For self-declared knowledge of French, informants were asked, "How well do you speak French? Very well, well, so-so, not well, or not at all." For self-declared use of French, informants were asked, "How often do you use French? Never, not frequently, sometimes, frequently, or always." For this last question, informants were asked a follow-up open-ended question, "Under what circumstances do you use French?" Although the use of self-reported proficiency indicators is common in research on language (Wharton 2000, Kim 2006), they can be inaccurate - future studies might attempt to gauge St. Lucians' English and French proficiency using standardized tests. To measure support for and attitudes toward the language, informants were asked the questions, "Is French or Spanish more important for children in St. Lucia to learn?" and "Should St. Lucians use more, the same amount of, or less French?" Follow-up openended questions were asked of the informants to probe why they support or do not support the learning of French versus Spanish among young St. Lucians and St. Lucians generally to use more, the same amount, or less French. Responses to these questions provide empirical evidence on the nexus between the French language and perceptions of national and cultural identity in St. Lucia.

\section{Postcolonialism, IDENTITy, AND LANGUAGE}

One of the main themes with which postcolonial theory deals is the development of national identities since the end of colonial rule. ${ }^{3}$ Postcolonial

3. Said 1979, 1993, Thiong'o 1986, Bhabha 1994, Narayan 1997, MacPhee 2006. 
theorists frequently view language through the dialectic of subjugation versus liberation (Thiong'o 1986). Early postcolonial theory developed in the Caribbean has tended toward the view that the region's European-origin languages - Spanish, French, English, Dutch, or, to a lesser extent, Danish - are tools of oppression, used to subjugate the Antillean creole vernaculars and, importantly, their speakers. Martinique's Frantz Fanon (1952), for example, equates speaking a standard European language with acceptance of the collective consciousness of the colonizer, which tends to associate the colonized with backwardness and ignorance. Catherine Walsh (1991) argues that the conflict caused by the psychological and cultural tension inherent in colonialism plays itself out in a skewed societal bilingualism - the establishment of a linguistic dualism in which the language of the colonizer asserts hegemony over the language of the colonized - and leads to the internalization of a subordinate identity among speakers of noncolonial languages. Aimé Césaire (1956) argues that restoration of a positive racial and cultural identity among colonized people is a way to negate colonialism's psychological and cultural distortions. In this view, the elevation of the social status of the Caribbean creole vernaculars is one way to restore a positive identity.

Derek Gregory (2004) argues that the colonial past is still present in postcolonial societies. The "colonial present" in postcolonial societies manifests itself in the continued stigma attached to native, noncolonial vernaculars. Such negative language attitudes have been especially prevalent in the Caribbean, although in the late 1960s and early 1970s creole cultural nationalism swept through the region seeking to negate and reverse these attitudes (Devonish 1986). Valerie Youssef (2002:184-85) also argues that the colonial past continues to play itself out in the present, via attitudes toward Caribbean creoles and a supposed West Indian alienation from Standard English or French:

It is worthy considering at this point that speakers of Creoles generally regard them as their own, even though they may devalorise them, and that they regard Standards or world languages, such as English and French, as the property of the former colonizers. The notion of rulership affects our minds particularly strongly, and so we focus on a history of Standards as the dominant languages, the languages of the oppressors, and reject them for these very connotations ... (S)ince the colonial past was characterized by widespread dismissal of the Creole language as "broken," it is small wonder that speakers do not feel comfortable regarding "whole" English or French as their own.

Institutions established during the colonial era persist in postcolonial societies and this inheritance has influenced generations coming of age since the actual period of colonization. In much of the formerly colonized world, Kamal Salhi (2004) argues, the most important cultural conflict that occurs is between European-imposed cultural models and indigenous ones. In the 
Caribbean, the tension is between European cultural norms and perceptions of Creoleness (Lavia 2006). In St. Lucia, postcolonial discourse has focused on harnessing indigenous knowledge and channeling this knowledge to promote national development (Lingard \& Pierre 2006). However, in St. Lucia - as in much of the postcolonial world - such discourse is moored to postcolonial identity politics. These politics seek to subvert cultural hegemonies, but do little to address actual structural inequalities (MacKinnon 2006, Szeto 2006). Postcolonial arguments revolving around issues of social justice also tend to be wedded to identity politics and counterhegemonic ideologies (HicklingHudson 2006). As such, postcolonial identity politics may be viewed as a form of aspirational politics (Lingard \& Pierre 2006). However, the goal of these politics is seldom attained (Avery 2006).

A condition of postcoloniality is that although national political sovereignty has been attained, indigenous cultural heritages in many parts of the world are in competition with global cultural and linguistic forms (Desai 2006). Intensified economic globalization, with the increased exchange of cultural and other goods and the movement of people and free flow of ideas it engenders, has changed the nature of ethnic, cultural, and national identities as well as patterns of language use. Supranational identities and language practices have emerged to compete with nationally based identities and ways of using language. In the new globalized economy, cultural uniformity has given place to cultural hybridity (Heller 2003). Due to the impact of globalization, identities are frequently diasporic, mobile, and transient (Savage, Bagnall \& Longhurst 2005). As such, strict dichotomies between the language and cultural property of the (former) colonizer and those of the (formerly) colonized have largely disintegrated. Identity is increasingly viewed as multiple, layered, and dynamic (Henriquez et al. 1984, Meinhof \& Galasinski 2005, Myers 2006). This is especially true in the West Indies (Knepper 2006). Language, in particular, allows for flexibility in identity. Through linguistic choices made, a person is able to consciously or unconsciously express dual or multiple identities, even in a single sentence (Blom \& Gumperz 1972, Warschauer 2000).

Many inhabitants of the contemporary postcolonial world have appropriated the language of the former colonial power and made it their own, claiming ownership of it as a step toward cultural freedom and independence (Fouet \& Renaudeau 1988). This is especially true of English - now the global lingua franca. In areas formerly under British colonial control, such as Nigeria and India, for example, new national varieties of English have emerged, replacing the formerly privileged British standard (Mesthrie 2006). This is also increasingly true in the postcolonial Francophone world, where French serves as an intercultural lingua franca. Here, French is no longer viewed as the exclusive cultural property of France (Salhi 2004). The maintenance of French as an official language in much of sub-Saharan Africa has been accompanied by the rise of Francophone identities that are 
used not only to distinguish Africans from France, but also from each other (Caitucoli 1998, Bissiri 2001, Ploog 2001). In addition, where French creole vernaculars exist, speakers often do not know whether particular words are creole or French, thereby blurring language-based lines of demarcation in identity formation and facilitating the existence of localized and regionalized Francophone identities in creole societies (de Robillard 2001).

Wendy Knepper (2006:70) states that in the Caribbean "identities, linguistic transformations, religious beliefs, music, cuisine, and aesthetic practices have been shaped by the fragmentation and intermixture of various traditions." As such, Caribbean efforts to promote a fixed Creoleness as a basis for identity politics are fraught with inherent limitations. In relation to postcolonial West Indian identity politics, Raphaël Confiant ${ }^{4}$ highlights the fluid nature of social facts underlying the project: "In the Antilles, the mixing was done by way of diffraction ... and far from erasing the evidence of their origins, the cultural contributions of the four continents were incorporated here and juxtaposed there without ever disappearing as such ... The Creole does not possess a new identity ... but new identities. The phenomenon of creolization invented from all the pieces a multiple identity." The multiplicity of identity inherent in the Caribbean creole experience and the current postcolonial, global era is accompanied by fluidity in West Indian patterns of language use, perceptions of language utility, and cultural and national identification with language.

Moreover, cultural nationalist movements asserting particular languages or language varieties have to contend with competing discourses, which often undermine partisan language planning efforts. In Quebec, for example, some cultural nationalists have sought to valorize folk elements of Québécois French culture - including uniquely Québécois characteristics of the French language - while others have sought to modernize the Québécois French language to make it more like the international standard and ready for use as a bureaucratic, scientific, and technical medium of expression (Handler 1988). In recent years, moreover, Puerto Ricans of all political inclinations and across the social spectrum have come to increasingly value their culture. As such, there have emerged competing discourses as to what constitutes Puerto Rican cultural identity. In terms of language, some Puerto Ricans hold to the view that Spanish is the only legitimate language of Puerto Rican identity, while others esteem both Spanish and English as constituent elements of Puerto Rican culture (Davila 1997).

In Martinique, although the French language now predominates and many Martiniquans consider themselves French, in literary and academic circles there has existed a movement, albeit marginal, to valorize creole language and

4. Créolité et francophonie: Un éloge de la diversité, Kapes Kreyol, available online at $<$ http://www.palli.ch/ kapeskreyol/articles/diversalite.htm>. 
culture since the late 1970s (Prudent 1993). Among Haitians both in Haiti and in the diaspora, French competes with Haitian Creole as a legitimate language of Haitian cultural identity (Buchanan 1979, Doucet 2000, Youssef 2002). Similarly, among Jamaicans at home and abroad, English and Jamaican Creole are subject to competing discourses on cultural nationalism, although the status of Jamaican Creole has improved considerably as a language of national identity vis-à-vis Standard English over the past two decades (Pryce 1997, Bryan 2004). In Suriname, although the English-based creole, Sranan, rose in status in tandem with growing cultural nationalist sentiment during the 1960s and 1970s, Dutch won out among competing discourses as the official medium of expressing Surinamese nationhood (St. Hilaire 1999, 2001). In Aruba, Bonaire, and Curaçao, however, Papiamento/Papiamentu has assumed a central and increasingly formal, official role as the legitimate expression of the islands' different cultural identities (Razak 1995, Oostindie 2005). However, in most avenues of formal education, which prepares islanders for tertiary educational opportunities in the Netherlands, Papiamento/Papiamentu continues to suffer from subordinate status vis-à-vis Dutch.

\section{SOCIOLINGUISTIC PORTRAIT OF ST. LUCIA}

In 1911, only 36.4 percent of all St. Lucians claimed to speak English. This proportion climbed to 56.5 percent in $1946 .{ }^{5}$ From survey fieldwork conducted on the island more than half a century later, approximately threequarters of the respondents professed to be able to speak English well or very well and only 2 percent indicated they could not speak the language at all, pointing to great gains in English proficiency since 1946. Initially, these gains did not come at the expense of Kwéyòl, but attest to a rising rate of societal bilingualism. ${ }^{6}$ However, by the late 1960s, Albert Valdman (1976) noted that Kwéyòl was in clear regression before English and predicted the language's death in the long term. Later, Lawrence Carrington (1984) also observed that Kwéyòl was waning in extent and influence throughout St. Lucia. Of the surveyed respondents, however, 71 percent professed to speak Kwéyòl well or very well and only 2 percent said that they could not speak the language at all. Nevertheless, more than a fourth of respondents professed to speak the language poorly - most of these were young people, possibly pointing to a shift away from the language.

Knowledge of French is considerably less widespread than either English or Kwéyòl. Estimates put the number of French speakers in St. Lucia at less than 10 percent of the population (Allen 1992, Grimes 1996). Dennis Ager

5. West Indian Census, 1950. Kingston: Government Printer.

6. West Indian Census, 1946. Kingston: Government Printer. 
(1996) valuates the number of real French speakers on the island at only 2,000, while Chaudenson (1992) asserts that a mere .5 percent of all St. Lucians are truly competent in Standard French. In contrast to these estimates, however, 16 percent of field research informants claimed to be able to speak French at least moderately well and 68 percent of the respondents said they could understand at least some spoken French. Of those who claimed to understand some French, nearly one-third - most of whom were young people - identified schooling in French as the way they acquired this ability, suggesting some success of the relatively recent efforts by national leaders and education policymakers to introduce French on the island. Although many St. Lucian informants report some French language ability, 48 percent of all respondents - including those who claimed no knowledge of the language - never use French and 27 percent use the language "not frequently" (see Graph 1). Slightly more than one-fifth claimed to use the language sometimes, while only 3 and 1 percent of the informants said that they use French frequently or always, respectively. Of those who claimed at least some use of French, 36 percent said they use it at work and/or with French-speaking tourists visiting the island. An additional third reported that they use the language when traveling to Martinique. Approximately one-quarter, composed entirely of students, use French in school. These data on linguistic knowledge and use point to St. Lucia's sociocultural orientation as nominally Francophone.

Graph 1. Frequency of French Language Use

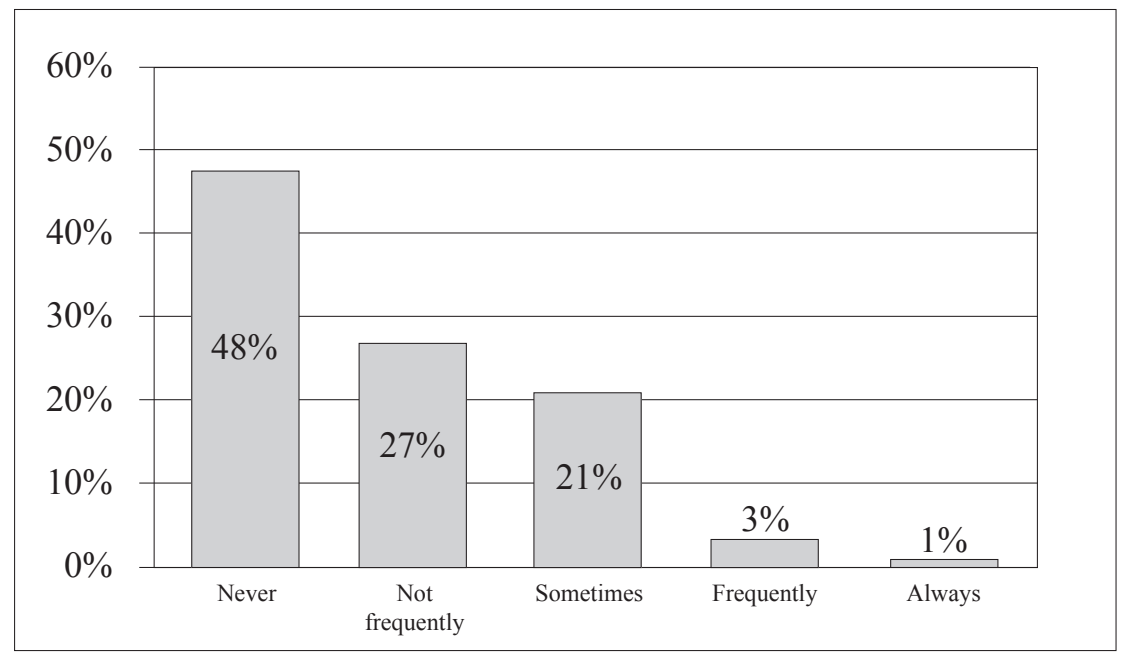


English is a highly prized possession among most St. Lucians. It is the language of education and employment both on the island and abroad - many St. Lucians emigrate to the United Kingdom, the United States, or Canada each year. In general, St. Lucians recognize and cherish their membership in the English-speaking world and consider English as much of a St. Lucian language as Kwéyòl. One-half of all informants in Monchy and nearly half of those in Castries expressed the belief that more English should be used on the island. Many of these indicated that St. Lucians should learn to speak better English. Many St. Lucians, particularly the well educated, are conscious of and concerned with the limited grasp of Standard English many of their compatriots have. The embracing of English is nearly universal among young people. A 19-year-old graduate of secondary school in Monchy who was looking for work at the time of the interview, stressed the need for more and better English among St. Lucians in order to prepare students for future employment, explaining the reason for young people's predilection for English:

\footnotetext{
The children nowadays learn ... are more interested in English. And when it comes to ... like, if they ... For example, when they go for employment, they more ... Nowadays, when you go to job interviews, they will not ask you questions in Patois. And they are not looking for any kind of English. They are looking for Standard English. So, I think they should raise their level of English and leave the Patois how it is. So, I think they should leave the Patois out of it [the school].
}

Only 2 percent of Monchy and 10 percent of Castries residents expressed the view that less English should be used. Of this minority, most thought that English threatened the survival of Kwéyòl. Although English is the undisputed language of opportunity and upward mobility and nearly all St. Lucians highly value English and will make great sacrifices to see that their children or grandchildren acquire a solid command of the language, most St. Lucians also deem Kwéyòl as a significant symbol of St. Lucian identity. Ninety-five percent of Castries informants and 93 percent of those in Monchy expressed the opinion that it is important for children to learn Kwéyòl. A 49-year-old working-class resident of Castries who speaks Kwéyòl fluently explained his support for the language: "It's a gift given by the All-Mighty. This is what you've been created of ... and if you have to neglect that language or leave it completely to adopt another language, you become an adopted child ... but not a legitimate child." A 19-year-old Castries respondent from a rural, working-class family added:

Creole is our culture. Creole we learn from Africa ... not just come from St. Lucia. I feel that Patois should be practiced. It should be practiced generally. That's our native language. That's our culture. Before English started, it was 
Patois. In ancient times, it was Patois your mother and grandmother used to talk to you. [But] when you come [to] Castries and live or when you come [to] Castries to go to school, they don't want you to speak Patois at all.

In line with these sentiments, since national independence a pro-Kwéyòl cultural nationalist movement has sought to elevate Kwéyòl as a full-fledged national language, instituting the annual Jounen Kwéyòl in celebration of St. Lucia's Afro-French, creole culture and seeking (unsuccessfully) to introduce Kwéyòl into the national school system as a language of instruction and literacy.

In spite of support for Kwéyòl for the role it plays in national identity, however, many St. Lucians have perceived a decrease in its societal use over time, providing further evidence of a shift away from the language and toward English. A 36-year-old seamstress in Monchy who uses mostly English and occasionally Kwéyòl with her children explained the sociolinguistic change in her community in these terms:

\begin{abstract}
I think less Patois is spoken now than when I was a child. Because I could remember when I was a little girl going to school, all the schoolchildren would be speaking Patois on the road to school. But now you hardly have any child that speaks Patois ... The parents are not speaking Patois like that ... time and time, you see, Patois is decreasing ... from the old generation that's dying out and the young generation that's coming in. The old generation speak Patois to their children. The children speak English to their children, you understand? So, therefore ... my great grandmother died already. And she speaking Patois alone. So, she died already. My grandmother can speak it [English] a little. And then my mother speak it to me fluent. So, I have to speak it to my children, too, you know? So, therefore, the Patois died. So, you hear the children on the way to school speaking English, you understand?
\end{abstract}

Standard French is a relative newcomer among St. Lucia's languages. Nevertheless, many St. Lucians identify with and embrace the language. St. Lucian attitudes toward French are partly informed by perceived linguistic affinities between French and Kwéyòl. Historically, the St. Lucian school system transmitted to children the idea that, "Patois is not a language, Patois cannot be written, Patois has no grammar, it is only broken French" (Carrington 1967:12). Jeffrey Allen (1992:24) views prevalent attitudes toward French and Kwéyòl as a factor undermining the status of Kwéyòl as an independent language in St. Lucia: "there's still a tendency for people to interpret the French Creole as an incorrect form of French and to associate it with French in some way. Therefore, the Creole loses its separate identity, a little of a separate identity." However, perceived linguistic affinities are auspicious for Franco-St. Lucian efforts to introduce French on the island. 
Perceived likenesses between French and Kwéyòl serve to bolster St. Lucian public support for French language instruction in the island's schools.

In competition with Spanish as the primary second (or third after Kwéyòl) language taught in St. Lucian schools, French clearly predominates, pointing to a Francophone cultural orientation among St. Lucians (see Graph 2). French and Spanish are the two main foreign languages taught in St. Lucian schools. The Spanish language has a strong presence in the Caribbean basin and the government of Venezuela subsidizes Spanish language instruction in St. Lucia. Nevertheless, when asked which language is more important for St. Lucian children to learn, most surveyed residents in Castries and Monchy, including those of school age, chose French over Spanish. Sixty-two and 58 percent of respective Castries and Monchy respondents expressed that French was more important for children to learn than Spanish. Most informants who favored French identified the many perceived similarities between the language and Kwéyòl as a justification for their preference. Only 12 and 18 percent of respective Castries and Monchy informants chose Spanish over French. Of the Castries respondents in this latter group, most were English speakers with little knowledge of Kwéyòl, and of the Monchy respondents, most spoke Kwéyòl fluently and related that with Kwéyòl young people could already communicate with French speakers - a view not supported by the experiences of those Kwéyòl-speaking St. Lucians who have had real contact with speakers of French - reflecting limited exposure to the Francophonie in rural Monchy relative to the more cosmopolitan, outward-oriented Castries.

Graph 2. Is French or Spanish More Important for Children to Learn?

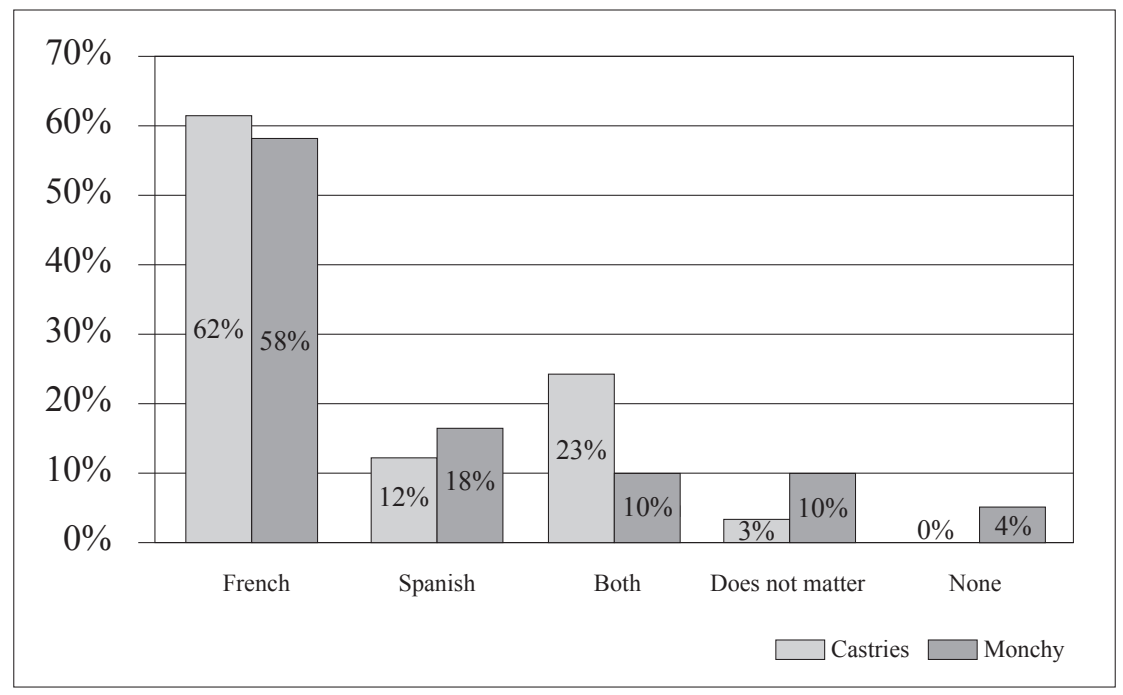


St. Lucians share few perceived cultural affinities with Ibero-America - but greater perceived cultural affinities with the Francophonie - and have relatively few real contacts with Spanish speakers. Respondents expressed that French is closer to St. Lucian culture than is Spanish. A 19-year-old Castries fisherman with a grade-school education put it in terms of racial and regional identity:

\begin{abstract}
You barely ever come across a Spanish person. A Spanish person would have to drop down from the sky, dem White people dem. The Caribbean is more English and French ... that's why ... we [St. Lucians] are in the center. We can understand English. We can understand French. We speak both. We are doing both. So, we are blessed.
\end{abstract}

In addition, some informants stressed the greater utility of French for international communication, suggesting that the Francophonie figures more importantly than Latin America among St. Lucians - in spite of the geographic closeness and demographic weight of the latter. Other informants highlighted the frequency of French-speaking tourists visiting St. Lucia as a reason for the importance of French.

In addition to preferring French over Spanish as the most important second (third) language of acquisition for children, respondents expressed the view that St. Lucians should, in general, use more French (see Graph 3). This is especially true in urban Castries, where residents have greater contact with foreign Francophone visitors on the island and have more experience traveling within the French-speaking Caribbean relative to the more insular residents of Monchy. Indeed, informants supporting the general increased use of French in St. Lucia cited contact with French-speaking visitors on the island, travel to different territories of the Francophonie, and the geographic closeness of Martinique to justify their responses. A 34-year-old Castries housewife put it succinctly: "You have a lot of French people who visit here. You have a lot of French people living here and a lot of St. Lucians go to Martinique to live or to visit." In addition, St. Lucians - who live in a materially poor nation and have a long history of economically motivated emigration - value the acquisition of French for the doors it potentially opens abroad. Another respondent, a 45-year-old hotel worker originally from the northwestern coastal village of Gros Islet emphasized the usefulness of French, as distinct from Kwéyòl, for the access it provides to the Francophonie:

it's true we're Patois speaking ... the French speaking is still different from the Patois ... and we have Martinique very close to us there. Plus, we are native country (sic) ... and then we could still go to France or ... there's this place in Canada you speak French. It's not Patois they speak there. 
Graph 3. Should St. Lucians Use More, the Same Amount or Less French?

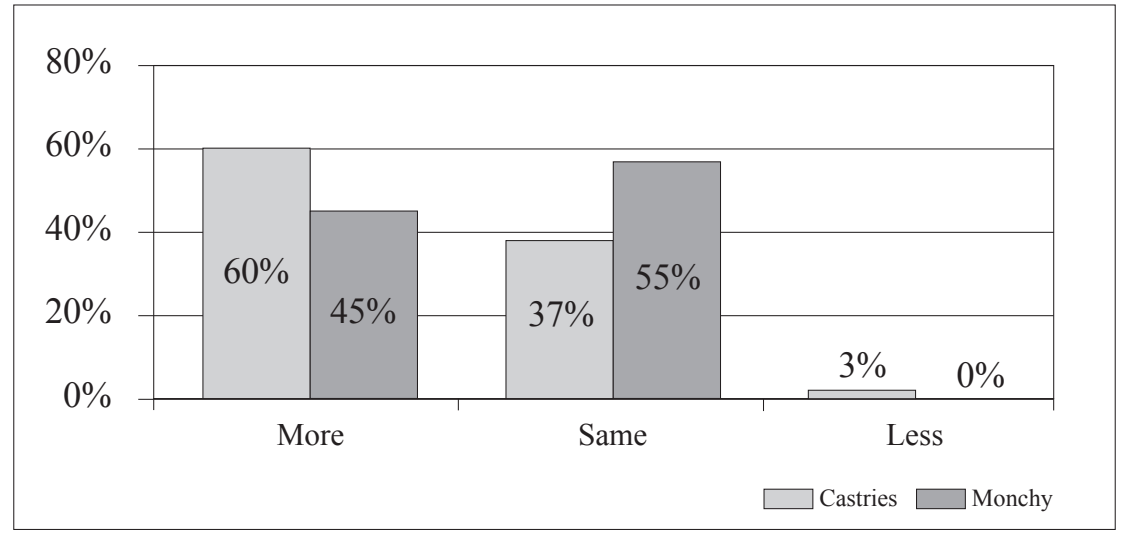

Many St. Lucians consider Kwéyòl to be "broken French" (Vaughan 1979, Carrington 1984). As such, some respondents conflated the Kwéyòl with the French, suggesting that support for the use of more French is related to support for the Kwéyòl language. A Monchy respondent in his forties who had partially completed grade school conveyed the following view:

This is our native tongue. Because of the French influence in our country, our first language is French. That's why we have the Patois. Some people say it's broken French, but I say it's almost like the French ... sometimes when you speak it, you find that certain words they use ... the real French ... we use, too.

Map 1. St. Lucia in the Eastern Caribbean

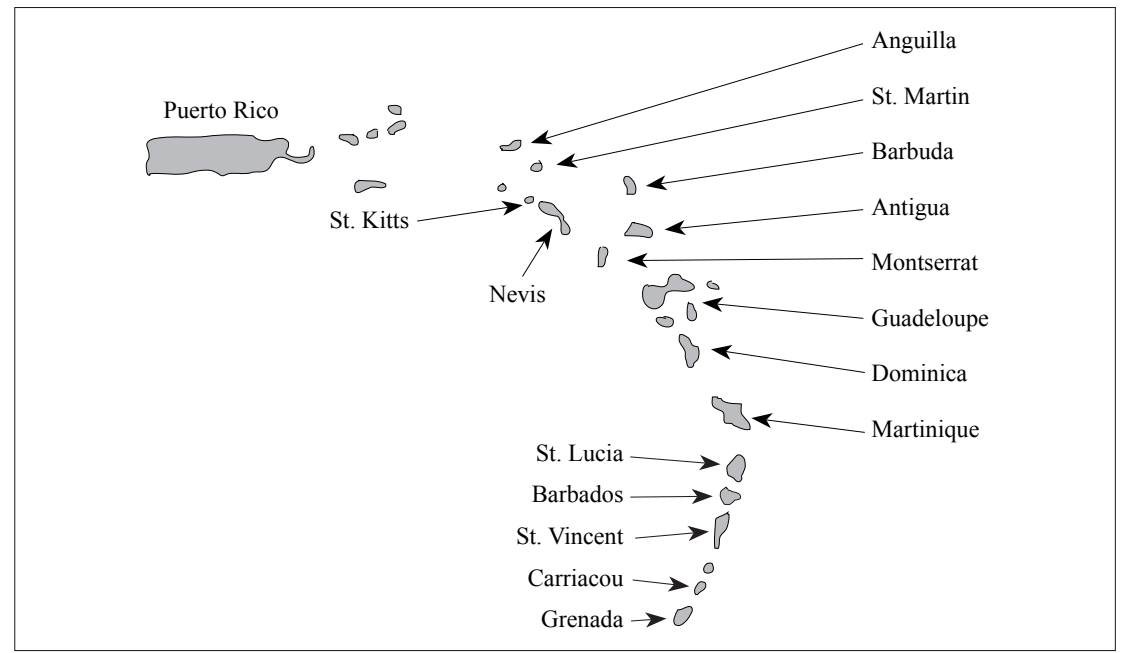


Many informants, including young people schooled in the language, affirmed that French improves the quality of Kwéyòl. Support for St. Lucians to use more French also appears to be related to the social desirability of the language. It is a social asset in St. Lucia to be able to speak French. Implicitly, acquisition of the language not only improves the Kwéyòl, it also improves the social status of individual St. Lucians and, by extension, the St. Lucian people.

One 39-year-old Castries respondent, supportive of greater use of French among St. Lucians, pointed to the fluidity of identity when it comes to language: "Creole speakers can change different identities by using a different language," and emphasized that this is what the neighboring Martiniquans do when they use French instead of Creole. This informant noted that the relatively well-off French-speaking Martiniquans project a sense of superiority vis-à-vis St. Lucian Kwéyòl speakers. A 23-year-old man living in Castries added: "I work in hospitality ... in the hotel ... we have a number of French guests coming down to St. Lucia and we find that sometimes we do not speak the language that well. It looks embarrassing. It looks bad." Another respondent, a 66-year-old farmer from the rural fringes of Castries who was born in Fort-de-France, Martinique, spoke more explicitly on the link between the ability to speak French and social acceptability:

I am very happy that many St. Lucians ... when you hear them speaking French, you cannot tell they are from here. You cannot distinguish whether they are Martiniquan or St. Lucian. I would like many of my people to learn the French language ... Those people who can speak French ... they have a feeling of grandeur ... of superiority.

Graph 4. Perceptions of Cultural Affinity: Martinique versus Barbados

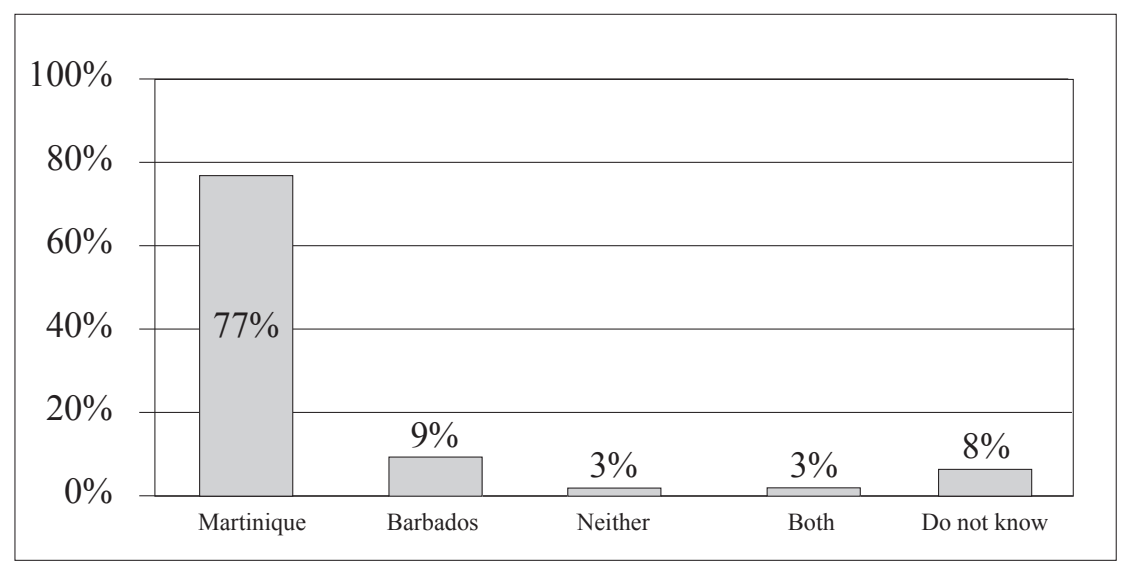


Of all the West Indian islands, Martinique and Barbados have played the largest role in St. Lucia's sociocultural development - in the seventeenth and eighteenth centuries, St. Lucia was settled predominantly by the French and slaves from Martinique and, under British colonial rule, Barbados was the administrative capital for the British Eastern Caribbean territories and the source of many post-1814 migrants to St. Lucia, including teachers coming to the island in early efforts to extend English-language formal education. When asked to identify which island is culturally most similar to St. Lucia, more than three-quarters of survey respondents identified Martinique (see Graph 4). Only 9 percent chose Barbados. Despite strong Barbadian influence relative to Martinique since the second half of the nineteenth century, most St. Lucians continue to feel culturally closer to the Martiniquans. Many of the respondents mentioned the shared history, culture, and language of the two islands in addition to the historic movement of and intermarrying between the two peoples as their reasons for choosing Martinique over Barbados. One 43-year-old Castries informant affirmed summarily, "We have a lot of French in us." Of the 9 percent who identified St. Lucia as culturally closer to Barbados, all spoke Kwéyòl poorly and most lived in Castries.

One respondent in his late forties who had been involved in the St. Lucian pro-Kwéyòl cultural nationalist movement, identified the historic cultural closeness between St. Lucians and Martiniquans as still in play and manifest in the area of inter-island cooperation in spite of political barriers between French-controlled Martinique and independent St. Lucia:

\footnotetext{
Right now there's a lot of cooperation between Martinique and St. Lucia. The Martiniquan people and the St. Lucian people have always been a very close people ... by virtue of distance and so on. However, politically things are a bit more complex ... a lot more complex. But the people have been very close. Historically, the people have been cooperating with one another.
}

Contemporary trips by St. Lucians to Martinique, the influx of Martiniquan tourists to St. Lucia in recent years, the growth in the popularity of zouk music from the French West Indies, access to Martiniquan radio broadcasts on the north of the island, and current Martiniquan logistical and material support of initiatives to teach French in St. Lucian schools provide continuance in historical patterns of inter-island cultural exchange. However, Martinique is politically a part of heavily centralized France, and St. Lucia an independent nationmember of the Organization of Eastern Caribbean States and CARICOM. As such, political cooperation between the two islands is limited.

Although St. Lucians tend to identify with the regional, Caribbean Francophonie - especially Martinique - they are less inclined to identify with metropolitan France. Slightly more of the respondents expressed that St. Lucia is culturally closer to England than to France (31 to 29 percent - see 
Graph 5. Perceptions of Cultural Affinity: France versus England

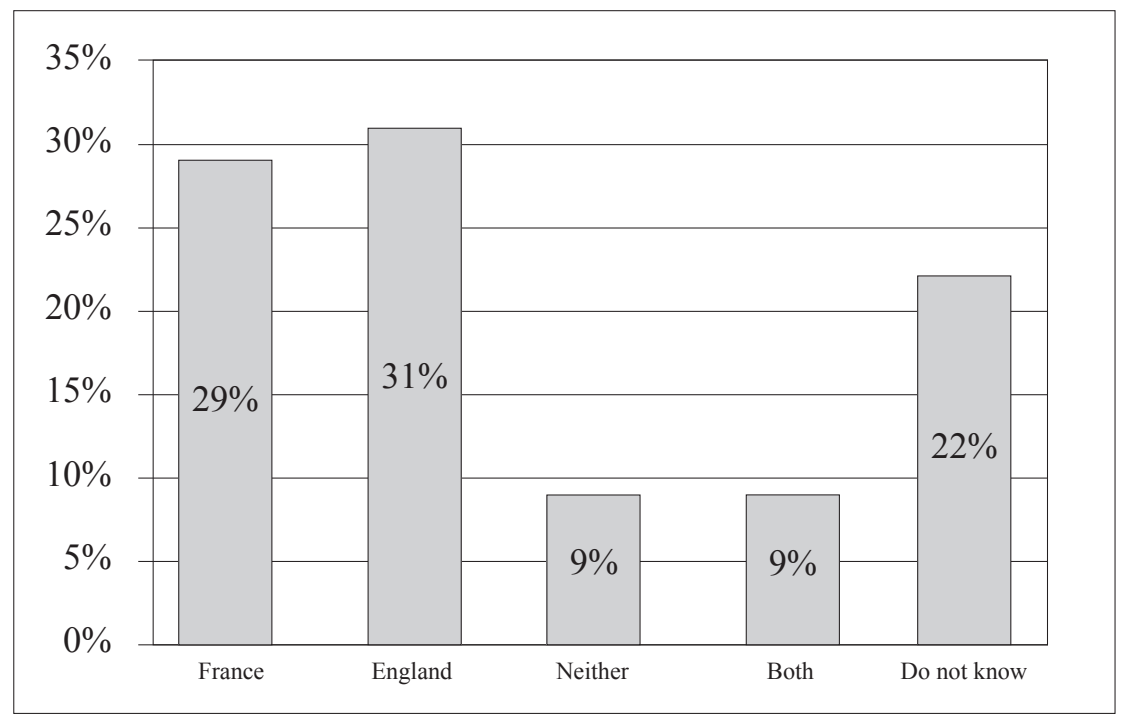

Graph 5). The informants tend to point to the island's colonial history under the British for evidence of cultural likeness with England. An upper-middleclass Castries man in his sixties explained,

I believe our colonial past has left us many legacies ... you may have noticed in me a bit of the English arrogance ... many who have gone to secondary school or the university tend to have a bit of this arrogance. We might like the French for their way of life, but when it comes to ... because of our education ... because we are educated by the English ... this English thing is in us.

Of the respondents who identified France as more culturally similar to St. Lucia, some specified language as the reason for the similarity. Others referred to St. Lucia's early history with the French. Several equated Martinique with France in making the assessment. Nearly one-third of all respondents said that they did not know which country is culturally closer to St. Lucia. Nine respondents thought neither country was culturally similar to St. Lucia. A handful of these laughed at the question, emphasizing cultural differences between the St. Lucians and the Europeans. 


\section{CONCLUSIONS}

In cultural nationalist discourse on language in postcolonial St. Lucia, rhetoric on English as a tool of colonial oppression never made it into the center of public or partisan debates - St. Lucians have long valued English. However, early pro-Kwéyòl cultural nationalism was infused with ideas associated with Liberation Theology and there was emphasis in programmatic planning to derive the means with which to alleviate the socioeconomic marginalization of monolingual Kwéyòl speakers. However, as the number of monolingual Kwéyòl-speaking St. Lucians declined in absolute and relative terms, this emphasis dissipated. Nevertheless, pro-Kwéyòl cultural nationalism on the island has persisted, shifting its focus to the elevation of Kwéyòl as symbol of St. Lucian cultural identity despite evidence of its waning as a familial and community language across the island. A result of this nationalist activity is high levels of support for and identification with the language among St. Lucians. However, this support and identification has not come with a diminution of support for and identification with Standard French, contrary to expectations arising from postcolonial theory. Indeed, perceived linguistic affinities between Kwéyòl and French serve to bolster support for the latter among St. Lucians.

Postcolonial institutions of social and cultural reproduction in St. Luciaincluding the schools - perpetuate the high status of English and the low status of Kwéyòl to the dismay of many pro-Kwéyòl cultural nationalists. Competing discourses as to the best language to advance St. Lucian nationhood and intensified globalization - through which the status of English, the global lingua franca, is enhanced - have also perpetuated the supremacy of English on the island. The French language has also benefited from postcolonial institutions of social and cultural reproduction with the introduction of French into the school system, competing discourses on language and St. Lucian cultural identity, and regionalized globalization. The French language has made gains in terms of users and status among those young people schooled in the language. Cultural identification with French among St. Lucians of all ages further bolsters the status of the language. Finally, St. Lucian feelings of strong cultural affiliation with predominantly French-speaking Martinique give St. Lucians perceptual and regional access to the global Francophonie and facilitate further St. Lucian embracing of the French language as St. Lucian cultural property. By embracing French in addition to English and Kwéyòl, St. Lucians can manipulate and express multiple identities. St. Lucians have long claimed cultural ownership of English and, increasingly since independence, Kwéyòl. Evidence suggests that they also claim cultural ownership of French.

There are competing discourses related to cultural identity on the island. St. Lucians value English pragmatically for the access it provides to opportunities for socioeconomic advancement on the island and to the wider world, 
Kwéyòl more emotively as a marker of St. Lucian national distinctiveness in the global community of nations, and French for its status enhancement qualities and for facilitating communication with neighboring Martiniquans. This fact and the Creole phenomenon that encourages multiple identity formation result in St. Lucian cultural identification with all three languages with no apparent contradictions. However, Kwéyòl has the most currency as a potent symbol of St. Lucian national identity. It is the most visible sign of St. Lucian cultural uniqueness when St. Lucians travel or live abroad. It does not appear, though, that the introduction of French in the island's public schools is a threat to the status of Kwéyòl. English is the high-status language of St. Lucian society, playing a role similar to Dutch in Suriname, French in the French West Indies and Haiti, and English in Jamaica and the other former British Antillean territories. On the contrary, St. Lucian efforts to expand knowledge of the language of Martinique and the global Francophonie may serve to bolster the status of Kwéyòl among St. Lucians by legitimizing the creole vernacular as a sister language to the regionally and internationally important French.

\section{REFERENCES}

AGER, DENNIS, 1996. "Francophonie" in the 1990s. Philadelphia: Multilingual Matters.

AleXAnder, L.-A. 1981. Patois Influence in St Lucian Speech. Cave Hill, Barbados: University of the West Indies.

Allen, JefFreY, 1992. Sainte Lucie: Description d'une île antillaise. MA thesis, Université Lumière II, Lyon, France.

AVERY, BRUCE, 2006. Postcolonial Studies and Beyond. Shakespeare Studies 34:20912.

BENNETT, ANDREW \& ELMAN COLIN, 2007. Qualitative Methods. Comparative Political Studies 40(2):111-21.

BHABHA, HOMI, 1994. The Location of Culture. Oxford: Routledge.

BISSIRI, AMADOU, 2001. Le français standard dans le champ artistique francophone: Les paradoxes d'une existence. Cahiers d'Etudes Africaines 41:163-64.

BLOM, JAN-PETTER \& JOHN GUMPERZ, 1972. Social Meaning in Linguistic Structures: Code-Switching in Norway. In Jan-Petter Blom \& John Gumperz (eds.), Directions in Sociolinguistics: The Ethnography of Communication. New York: Holt, Rinehart \& Winston.

BREEN, HeNRY, 1844. St. Lucia: Historical, Statistical and Descriptive. London: Longman, Brown, Green \& Longman. 
Bryan, BeVERly, 2004. Jamaican Creole: In the Process of Becoming. Ethnic and Racial Studies 24:641-59.

BUCHANAN, SUSAN HUELSEBUSCH, 1979. Language and Identity: Haitians in New York City. International Migration Review 13:298-313.

CAITUCOLI, ClaUde, 1998. Francophonie et identité au Burkina Faso: Eléments pour une typologie des locuteurs francophones. In A. Batiana \& G. Prinitz (eds.), Francophonies africaines. Rouen, France: Université de Rouen, pp. 9-20.

CARrington, LaWrence, 1967. St Lucian Creole: A Descriptive Analysis of Its Phonology and Morpho-syntax. PhD thesis, University of West Indies, St. Augustine, Trinidad.

—, 1984. St Lucian Creole. Hamburg, Germany: Helmut Buske Verlag.

CASSAN, PIERRE (ed.), 1996. Etat de la francophonie dans le monde. Paris: La Documentation Française.

CÉSAIRE, AIMÉ, 1956. Cahier d'un retour au pays natal. Paris: Présence Africaine.

CHAUDENSON, ROBERT, 1979. Les créoles français. Paris: Fernand Nathan.

—, 1992. Des îles, des hommes, des langues. Paris: L'Harmattan.

DalPhinis, Morgan, 1985. Caribbean and African Languages: Social History, Language, Literature and Education. London: Karia Press.

Davila, Arlene M., 1997. Sponsored Identities: Cultural Politics in Puerto Rico. Philadelphia PA: Temple University Press.

Desai, GaURAV, 2006. Capitalism, Sovereignty and the Dilemmas of Postcoloniality. Boundary 2(33):177-201.

DEVONISH, HUBERT, 1986. Language and Liberation: Creole Language Politics in the Caribbean. London: Karia Press.

DouCET, R., 2000. Creole Language Instruction in Haiti. Paper presented at the Fifth International Creole Language Workshop, Florida International University, Miami.

DUMONT, PIERRE, 2004. L'enseignement du français en Caraïbes. Paper presented for the conference "Etats des lieux de l'enseignement du français et des politiques linguistiques en francophonie," Castries, St. Lucia.

EDWARD, M., 1989. The Use of Kwéyòl in the Language Arts Curriculum: Creating Bilingual Classrooms in Rural St Lucia. Unpubl. paper for the Ontario Institute for Studies in Education, Toronto, Canada.

FANON, FRANTZ, 1952. Peau noire, masques blancs. Paris: Présence Africaine.

FOUET, FRANCIS \& RENAUDEAU, RÉGINE, 1988. Littérature africaine: L'engagement. Dakar: Les Nouvelles Éditions Africaines. 
FRANK, DAVID, 1993. Political, Religious and Economic Factors Affecting Language Choice in St Lucia. The International Journal of the Sociology of Language 102:39-56.

Garrett, PAUl, 2000. "High" Kwéyòl: The Emergence of a Formal Creole Register in St Lucia. In John H. McWhorter (ed.), Language Change and Language Contact in Pidgins and Creoles. Philadelphia PA: John Benjamins, pp. 63-102.

—, 2003. An "English Creole" That Isn't: On the Sociohistorical Origin and Linguistic Classification of the Vernacular English in St Lucia. In Michael Aceto \& Jeffrey P. Williams (eds.), Contact Englishes of the Eastern Caribbean. Philadelphia PA: John Benjamins, pp. 155-210.

_, 2006. Contact Languages as "Endangered" Languages: What Is There to Lose? Journal of Pidgin and Creole Languages 21:175-90.

GREGORY, DEREK, 2004. The Colonial Present: Afghanistan, Palestine, and Iraq. Malden MA: Blackwell Publishing.

GRIMES, BARBARA (ed.), 1996. Ethnologue: Languages of the World. Dallas TX: Summer Institute of Linguistics.

HANDLER, RICHARD, 1988. Nationalism and the Politics of Culture in Quebec. Madison: University of Wisconsin Press.

HELLER, MONICA, 2003. Globalization, the New Economy and the Commodification of Language and Identity. Journal of Sociolinguistics 7:473-92.

HenriQueZ, Julian et al., 1984. Changing the Subject: Psychology, Social Regulation and Subjectivity. New York: Methuen.

HICKLING-HUdSON, ANNE, 2006. Cultural Complexity, Post-Colonialism and Educational Change: Challenges for Comparative Educators. International Review of Education 52(1/2):201-18.

ISAAC, MARTHA, 1989. French Creole Influence in the Written English of St Lucian Secondary Students. MA thesis, University of West Indies, Cave Hill, Barbados.

Kim, Ye-Kyoung, 2006. Linguistic and Social Capitals. PhD dissertation, Ohio State University, Columbus.

KNAPIK, MIRJAM, 2006. The Qualitative Research Interview: Participants' Responsive Participation in Knowledge Making. International Journal of Qualitative Research 5(3): $1-13$.

KNEPPER, WENDY, 2006. Colonization, Creolization, and Globalization: The Art and Ruses of Bricolage. Small Axe 11:70-86.

LAVIA, JENNIFER, 2006. The Practice of Post-Coloniality: A Pedagogy of Hope. Pedagogy, Culture and Society 14(3):279-93.

Lingard, Bob \& Kentry D. JN Pierre, 2006. Strengthening National Capital: A Postcolonial Analysis of Lifelong Learning Policy in St Lucia, Caribbean. Pedagogy, Culture and Society 14:295-314. 
LOWENTHAL, DaVID, 1972. West Indian Societies. New York: Oxford University Press.

MacKinnon, Katharine, 2006. An Orthodoxy of "the Local": Post-Colonialism, Participation and Professionalism in Northern Thailand. Geographic Journal 172:22-34.

MACPHEE, GRAHAM, 2006. A Historical Companion to Postcolonial Thought in English. College Literature 33:220-22.

MaY Szeto, Mirana, 2006. Identity Politics and Its Discontents. Interventions: The International Journal of Postcolonial Studies 8:253-75.

MEINHOF, ULRIKE HANNA \& DARIUSZ GALASINSKI, 2005. The Language of Belonging. New York: Palgrave Macmillan.

MESthrie, RAJEND, 2006. World Englishes and the Multilingual History of English. World Englishes 24:381-90.

MYERS, GREG, 2006. Where Are You From?: Identifying Place. Journal of Sociolinguistics 10:320-43.

Narayan, Uma, 1997. Dislocating Cultures: Identities, Traditions, and Third World Feminism. Oxford: Routledge.

OOSTINDIE, GERT, 2005. Paradise Overseas: The Dutch Caribbean: Colonialism and Its Transatlantic Legacies. London: MacMillan Caribbean.

PlOOG, KATJA, 2001. Le non-standard entre norme endogène et fantasme d'unicité: L'épopée abidjanaise et sa polémique intrinsèque. Cahiers d'Etudes Africaines 163-64: n.p.

PRUdent, LAMBERT-FeliX, 1993. Political Illusions of an Intervention in the Linguistic Domain in Martinique. International Journal of the Sociology of Language 102:135-48.

PRYCE, JEAN, 1997. Similarities between the Debates on Ebonics and Jamaican. Journal of Black Psychology 23:238-41.

RAZAK, VICTORIA, 1995. Culture under Construction: The Future of Native Arubian Identity. Futures 27:447-59.

ROBILlARD, DIDIER DE, 2001. En lizje kokê patat en lizje vez gardjê/La linguistique peut-elle passer «entre-les-langages»? Cahier d'Etudes Africaines 163-64:n.p.

SAID, EDWARD, 1979. Orientalism. New York: Vintage.

—, 1993. Culture and Imperialism. New York: Vintage.

St. Hilaire, AOnghas, 1999. Language Planning and Development in the Caribbean: Multi-Ethnic Suriname. Language Problems and Language Planning 23:211-31.

—, 2000. It's Our Culture: Global Process, Community Development and Language Survival in Louisiana and St Lucia. PhD dissertation, Johns Hopkins University, Baltimore MD.

-, 2001. Ethnicity, Assimilation, and Nation in Plural Suriname. Ethnic and Racial Studies 24:998-1019. 
—, 2003. Globalization, Urbanization and Language in Caribbean Development: The Assimilation of St Lucia. New West Indian Guide 77:65-84.

SALHI, KAMAL, 2004. Rethinking Francophone Culture: Africa and the Caribbean between History and Theory. Research in African Literatures 35:9-29.

SAmuel, KenNedy, 1992. Towards a National Language Policy in St. Lucia. Media Development 1: Journal of the World Association for Christian Communication 24:11-13.

SAVAGe, Mike, Gaynor BAgnall \& Brian LONGHURSt, 2005. Globalization and Belonging. London: SAGE Publications.

Thiong'o, Ngugi Wa, 1986. Decolonising the Mind: The Politics of Language in African Literature. London: J. Currey.

VALDMAN, ALBERT, 1976. Certains aspects sociolinguistiques des parlers créoles français aux Antilles. Ethnies 3:7-22.

VAughan, Robert, 1979. The Development of a Dictionary of Selected Words and Phrases of the Creole Language as Spoken by the People of St Lucia. PhD dissertation, University of Sarasota FL.

WALSH, CATHERINE E., 1991. Pedagogy and the Struggle for Voice: Issues of Language, Power, and Schooling for Puerto Ricans. New York: Bergin \& Harvey.

WARschaUer, MARK, 2000. Language, Identity and the Internet. In B. Kolko, L. Nakamura \& G. Rodman (eds.), Race in Cyberspace. New York: Routledge, pp. 151-70.

Wharton, GLenN, 2000. Language Learning Strategy Use of Bilingual Foreign Language Learners in Singapore. Language Learners 50:203-43.

YOUSSEF, VALERIE, 2002. Issues of Bilingual Education in the Caribbean: The Cases of Haiti, and Trinidad and Tobago. International Journal of Bilingual Education and Bilingualism 5:182-93.

AONGHAS ST. HILAIRE

U.S. Census Bureau, ACSD

Washington DC 20277-6081, U.S.A.

<amsthilaire@yahoo.com> 